Research, part of a Special Feature on Global Water Governance: Challenges and Future Scope

\title{
Comparing Global Coordination Mechanisms on Energy, Environment, and Water
}

Susanne Schubert and Joyeeta Gupta

\begin{abstract}
Increasingly, coordination mechanisms are being created at the United Nations (UN) level to enhance systemwide synergies; however, there is relatively little scientific research on these bodies. Against this background, we compare the mandates, structures, and outputs of three UN coordination mechanisms, the UN Environment Management Group, UN-Energy, and UN-Water, to understand what features enhance their ability to coordinate. We conclude that there are three key design elements that possibly enhance the ability of such mechanisms to coordinate. However, although coordination mechanisms are the easiest to set up, because they create the least political upheaval and are relatively cheap, these very characteristics hinder their ability to actually steer the bodies in their sector in such a way that synergy is optimized, duplications and contradictions are reduced, and a common strategy is adopted. Such coordination bodies can contribute to agenda setting, knowledge sharing, providing a discussion forum, and bringing together stakeholders and experts.
\end{abstract}

Key Words: coordination mechanism; global energy governance; global environmental governance; global water governance; United Nations; UN-Water

\section{INTRODUCTION AND METHOD}

Because this Special Feature covers global water governance in general, this paper focuses on specific organizational approaches in the context of broader United Nations (UN) reform processes. Organizational approaches are a distinct element of governance approaches. Although organizational approaches focus more on the structure of the process of governance, governance includes structure; substantive issues, e.g., principles, concepts, and tools; and procedural issues, rules of procedure, voting, etc.

Some potential options for redesigning the organizational framework of global governance institutions are theoretically available (Gosovic 1992, Keohane 1993, Esty 1994, Young et al. 1996, Agarwal et al. 1999, Gibson 1999, Biermann 2002, Gupta 2002, 2005, Oberthü 2002, von Moltke 2002, Young 2002, Pahl-Wostl et al. 2008, Biermann et al. 2012a,b). These include a hierarchical, integrated, sustainable development organization such as a possible World Sustainable Development Organization; a hierarchical single-issue body, such as a United Nations Environment Organization (UNEO); a high-level advisory group such as the Secretary-General's Advisory Body on Water and Sanitation; nonhierarchical focal points; coordination bodies; the strengthening of individual bodies; promoting coordination through the progressive development of international law, for example, through a law on sustainable development; regime clustering; decentralized network organizations; and a business-as-usual approach that allows multiple processes to arise, exist, compete, and function.

In recent years, many coordination bodies have been established within the UN. These include UN-Water, UNOceans, UN-Energy, United Nations Forum on Forests, and the UN Environment Management Group (UN EMG). Although there has been considerable research on the kind of governance needed at the global level in general (Biermann et al. 2012a,b), in relation to bureaucracies (Bauer et al. 2012), to corporations (Tienhaara et al. 2012), and to transnational environmental regimes (Pattberg 2012), there are hardly any scientific publications on coordination mechanisms. Hence, we address the question, what does an examination of coordination mechanisms teach us about improving coherence in global water governance?

We analyze three coordination mechanisms. These mechanisms were selected based on two criteria: (a) the nature of the issue area and its relation to water; and (b) that it should be operational for some time. UN-Water, operational since 2003, was chosen as the key case study. UN-Energy, operational since 2003, and UN Environment Management Group, operational since 2001, also were selected. The case selection reflects different sectors of environmental governance and, in the context of this Special Feature, reflects on experiences of UN Water against the background of comparable, although different, mechanisms. We analyzed these mechanisms primarily based on their own documentation and products, on internal and external evaluations where available, and on confidential interviews with experts, conducted in a detailed Master of Science thesis (Schubert 2010).

\section{BACKGROUND TO COORDINATION MECHANISMS}

Historically, coordination at the UN level goes back to the UN Charter of 1945 (United Nations 1945), when the United Nations Economic and Social Council (ECOSOC) was mandated to ensure coordination among the specialized 
agencies (UN Charter: Art. 57, 63). ECOSOC established the Administrative Committee on Coordination (ACC), which was replaced in 2001 by the Chief Executives Board (CEB). The board promotes coordination and cooperation on substantive and management issues facing UN organizations. It has three subcommittees: the United Nations Development Group (UNDG), the High-Level Committee on Programmes (HLCP), and the High-Level Committee on Management (HLCM).

The three subcommittees of the Chief Executives Board are mandated to undertake coordination activities. The UNDG focuses on operational activities for development at the country level, promoting measures that should improve strategic and operational coherence and effectiveness. The HLCM identifies, promotes, and coordinates management reforms to improve productivity, efficiency, and effectiveness across the UN system. The HLCP pays particular attention to cross-cutting and multisectoral issues and priority areas to which no lead agency has been assigned; coordinates programs and operational areas as well as knowledge and information sharing; undertakes strategic planning, policy and program development and implementation; and maintains an overview of developments in these areas. It aims to strengthen convergence and cohesion of related programs and to maximize their impact in support of system-wide objectives, to support the preparation and follow-up to UN conferences, and to serve as a forum for interagency dialogue on the development and launching of new initiatives of system-wide concern (Chief Executives Board 2002).

Although coordination has been a key task of the Economic and Social Council since 1945, it is only since the seminal Brundtland Report of 1987 that the interconnectedness of environmental, developmental, and economic issues was given more emphasis. The present need is probably more for coordination than for new bodies. Since the 1992 Rio Conference on Environment and Development, there has been renewed focus on ensuring system-wide coherence and coordination in the global arena (United Nations Sustainable Development 1992). This led to a number of coordination mechanisms, set up in the early 2000s. After the World Summit in 2005, the Secretary-General called for the establishment of the High-Level Panel on System-wide Coherence, to study "United Nations System-Wide Coherence in the Areas of Development, Humanitarian Assistance and the Environment." Composed of 15 members, mainly prime ministers, ministers, and presidents or former presidents of member states, the panel published Delivering as One, which proposes a framework for a more unified and coherent UN structure in the fields of development, humanitarian assistance, and the environment (UN Secretary-General's High Level Panel 2006). In August 2010, the High-Level Panel on Global Sustainability was established. Its 2012 report (UN Secretary-General's HighLevel Panel on Global Sustainability 2012), published in preparation for the 2012 Rio+20 summit, recommended that governments should stop thinking in terms of 'silos' and instead focus on coordination and integration. The report recommended the establishment of a Global Sustainable Development Council. The Rio+20 outcome document reemphasizes global consensus on the need for better coordination by discussing coordination 21 times in the document (United Nations 2012). It also decided to establish a new universal intergovernmental high-level political forum to deal with sustainable development issues (United Nations 2012).

The idea of coordination mechanisms is that they will have the power to steer other bodies in a way that synergies are maximized while duplications and counterproductive measures are minimized. To assess whether this happens, we examine (a) the mandates of these bodies; (b) the organizational setup of the bodies; and (c) the kinds of products they aim to generate.

\section{UN ENVIRONMENT MANAGEMENT GROUP, UN- ENERGY, AND UN-WATER: THE FACTS}

Currently, three subgroups are working under the HLCP and reporting to it (see Fig. 1): UN-Water, established in 2003 and focusing on freshwater issues; UN-Energy, established in 2003, first session 2004; and UN-Oceans, established in 2003, first session in 2005, focusing on marine issues and posttsunami challenges (Chief Executives Board 2003a). To ensure coordination in the field of environment and human settlements, the UN Environment Management Group (UN EMG) was founded in 1999 and is acting in close relation to United Nations Environment Programme (UNEP) and cooperating with UN-Habitat for a Better Urban Future (UNHabitat) and the Commission for Sustainable Development.

\section{UN Environment Management Group}

Following the UN Conference on the Human Environment in 1972, the UNEP was set up. Its mission is "to provide leadership and encourage partnership in caring for the environment by inspiring, informing, and enabling nations and peoples to improve their quality of life without compromising that of future generations" (UNEP 2005:2). Since then, environmental policy making has permeated other UN agencies. In 1998, the Task Force on Environment and Human Settlements recommended the foundation of the UN Environment Management Group (UN EMG) to improve coordination and communication on environmental and human settlement activities inside the UN System (United Nations General Assembly 1999). The governing councils of UNEP and UN-Habitat supported this, and in 1999 the General Assembly decided to establish an environmental management group "for the purpose of enhancing inter-agency coordination in the field of environment and human settlements" (United Nations General Assembly 1999:3). The Administrative Committee on Coordination of the Chief Executives Board 
Fig. 1. Coordination bodies (green) and organizations with which they are closely cooperating. Key: UN-Habitat, UN-Habitat for a Better Life. UNEP, United Nations Environment Program. COPs of the MEAs, Conference of the Parties of the Multilateral Environment Agreement. CSD, Commission on Sustainable Development. CEB, Chief Executives Board. DESA, United Nations Department of Economic and Social Affairs. UNDG, United Nations Development Group. HLCP, High-Level Committee on Programmes. HLCM, High-Level Committee on Management. UN EMG, United Nations Environment Management Group.

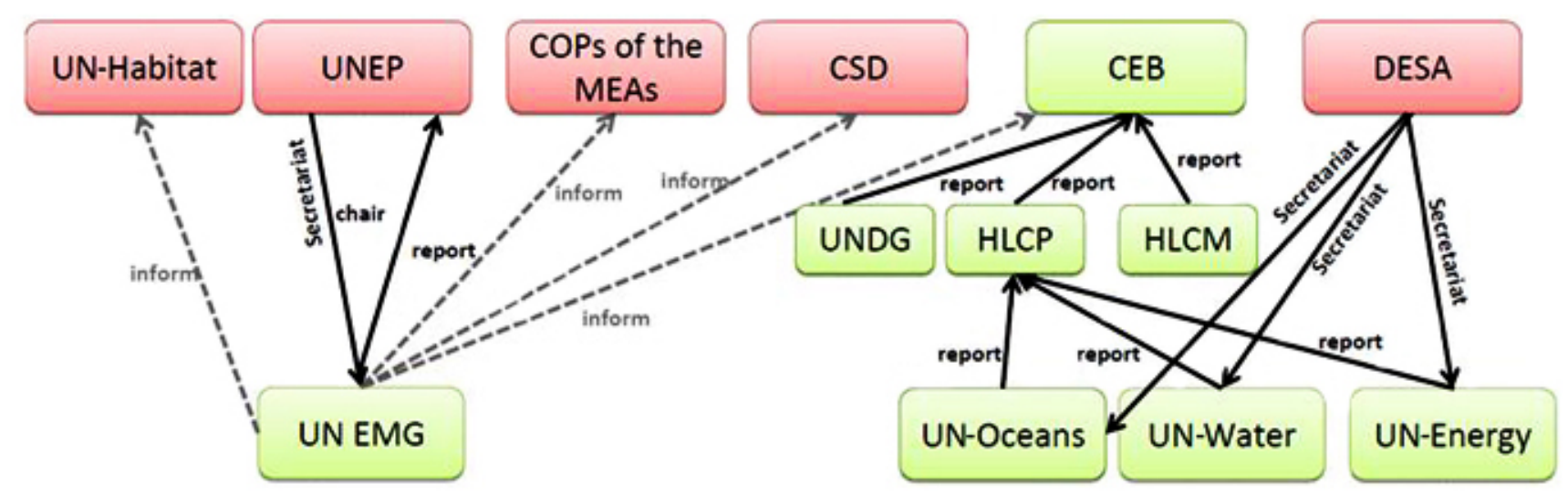

endorsed the Terms of Reference in 1999. The first meeting of the UN EMG took place in January 2001 in Geneva. The UNEMG, closely linked to UNEP, coordinates environmental and human settlement issues, operating through an issuemanagement approach.

\section{Mandate}

The EMG's mandate is to provide a coordinated response, facilitate joint action on newly emerging issues of environment and human settlement interagency concerns, and contribute to the compatibility of different approaches (Governing Council of the UNEP/Global Ministerial Environment Forum 2004). It is the mechanism used by UNEP to fulfill its own coordination tasks. It therefore aims to promote linkages and to provide a forum for discussion, information sharing, and data exchange. It involves UN and non-UN partners and aims to enhance the environment and human settlement perspective by supporting UNEP and Habitat in interagency mechanisms, especially the Commission for Sustainable Development (Governing Council of the UNEP/Global Ministerial Environment Forum 2004).

\section{Structure}

The EMG has a two-tiered structure: a senior-level decisionmaking body (Environment Management Group), composed of senior-level officials from the member organizations, chaired by the Executive Director of UNEP; and time-bound ad hoc Issue Management Groups (IMG), composed of the EMG members who are involved in the specific issue, normally led by UNEP and set up temporarily by the seniorlevel decision-making body (Governing Council of the UNEP/
Global Ministerial Environment Forum 2004). The EMG members are specialized agencies, programs, and organs of the UN System, which are active in the field of environment and human settlements, and include the secretariats of multilateral environmental agreements. As of June 2012, the EMG had 46 members.

Representatives of international nongovernmental organizations may participate in meetings of the EMG and the IMGs, but only by invitation. UNEP provides secretariat support to the EMG in Geneva, but its move to New York is already planned (Governing Council of the UNEP/Global Ministerial Environment Forum 2004).

\section{Activities}

EMG's work has followed up on the World Summit on Sustainable Development (WSSD 2002) and the Johannesburg Plan of Implementation, or JPOI (WSSD 2002). The EMG divides its activities among programmatic issues (IMGs on Biodiversity, Land, and Green Economy); management issues (sustainable procurement, climate neutrality, and a coherent approach to sustainable management in the UN); and operational issues (consultative process on Environmental and Social Safeguards in the UN).

The IMG on Biodiversity's Report for the 2010 special session of the General Assembly and the Conference of the Parties 10 of the Convention on Biodiversity in October 2010 presented a perspective on the post-2010 challenges, strategies, programs, plans, and initiatives to help inform the formulation of future biodiversity targets (Environment Management Group, Issue Management Group on the 2010 Biodiversity 
Targets 2009). The IMG on Land was established as a response to the land challenges identified in UNEP's Global Environment Outlook 4 and works on drylands and options for a coherent UN-System-wide contribution to land challenges, including the implementation of the 10-year strategic plan of the United Nations Convention to Combat Desertification, or UNCCD (UNEP 2007). The IMG on Green Economy prepared an interagency assessment report on the UN System's activities on green economy for the UN Conference on Sustainable Development 2012 (Environment Management Group Secretariat 2010). The key findings were presented during a side-event to the Rio+20 conference (Environment Management Group 2011). Past IMGs have dealt with diverse issues, including energy, industrial development, and capacity building (Schubert 2010). The IMG on "harmonization of reporting for biodiversity-related conventions" resulted in bilateral meetings on harmonization between UNEP and the secretariats of the ecosystem-related conventions (Environment Management Group of the United Nations Environment Programme 2001).

\section{UN-Energy}

Unlike environment, energy governance is not concentrated in any UN agency, but is dispersed through the UN system. The only UN agency focusing on energy is the International Atomic Energy Agency (IAEA). This is partly attributable to the notion of energy security, which implies that most states did not wish to give up control over energy governance to an international agency (cf. Florini and Sovacool 2009, Goldthau and Witte 2009, Gupta and Ivanova 2009, KarlssonVinkhuyzen 2010, Gupta 2012). However, the negative externalities of energy production, distribution, and consumption systems call for increasing global governance on energy. In September 2003, the HLCP reviewed the collaborative arrangements within the $\mathrm{UN}$ and recommended stronger system-wide cooperation in the field of energy (Chief Executives Board 2003b). Endorsed by the Chief Executives Board in 2003, the first meeting of UN-Energy took place in July 2004 at UNESCO Headquarters in Paris (UN-Energy 2004, as cited in Schubert 2010).

\section{Mandate}

UN-Energy's mandate is to ensure coherence and an effective system-wide follow-up of the WSSD and its JPOI. It aims to provide a forum for sharing knowledge, information, good practices, and experiences and to maintain an overview of and strengthen synergies between ongoing and planned work within the UN System. It promotes joint programming and harmonization and cooperation in energy-related activities, identifies linkages and further areas for cooperation as well as unmet needs for further action, and draws lessons from past experiences in interagency cooperation on energy. Its field of work shows similarities with those of the International Energy Agency at the Organisation for Economic Co-operation and Development (OECD).

\section{Structure}

UN-Energy has 20 members. Representatives of UN-Energy's members at the Senior Programme Manager's Level (SPM level) decide on its work program. Most activities are carried out in open-ended clusters. UN-Energy offers no permanent or formal partner status (UN-Energy 2005a). It cooperates with non-UN partners on an ad hoc basis, addressing them at international conferences. The chairmanship rotates among the members, by election. The secretariat is provided by the United Nations Department of Economic and Social Affairs (UN DESA). UN-Energy reports through the High-Level Committee on Programs (HLCP) to the Chief Executives Board (UN-Energy 2005b).

\section{Activities}

UN-Energy aims to promote the relevance of energy for the achievement of the Millennium Development Goals through reports and case studies to complement the SecretaryGeneral's report on energy for CSD-14. It organized side events at CSD-14 and CSD-15 (UN-Energy 2007) and took part in a number of energy-related conferences.

UN-Energy has conducted preliminary mapping exercises to assess options for improving synergies and has formed clusters on access to energy services, promotion of energy efficiency, and renewable energy. The Energy Access Cluster is led by DESA, UNDP, and the World Bank. This cluster worked on the follow-up UN-Energy publication on the importance of energy to reach the Millennium Development Goals (MDGs), funded by the World Bank, the Energy Sector Management Assistance Programme (ESMAP), and UNDP. The report was launched during the High-Level Meeting on the Millennium Development Goals in September 2008 (UN-Energy 2008, as cited in Schubert 2010). The Energy Efficiency Cluster, led by the United Nations Industrial Development Organization (UNIDO) and IAEA, aims to deliver a clear message to policy makers on the advantages of promoting energy efficiency through analytical decision-support tools at the national level (UN-Energy 2008a).

The Renewable Energy Cluster, led by the Food and Agriculture Organization of the United Nations (FAO) and UNEP and supported by the United Nations Educational, Scientific and Cultural Organization (UNESCO), has focused on bioenergy (UN-Energy 2008b), and its results are used by FAO and UNEP to develop tools for policy makers for dealing with sustainable biofuels. In cooperation with the Global BioEnergy Partnership, the cluster also organized a side event on bioenergy during the High-Level Conference on Food Security in June 2008 and on the link between food security and bioenergy for the 17th session of the Commission on Sustainable Development (CSD-17) in May 2009 (UNEnergy 2008c). 


\section{UN-Water}

Although water governance has been on the local to international agenda for centuries (Dellapenna and Gupta 2009), no single UN agency has an exclusive water mandate, and water governance has been spread through the UN system (Dellapenna and Gupta 2008, Pahl-Wostl et al. 2008). However, there was an increasing demand for a coherent vision and policy on water by the High-Level Committee on Programmes (HLCP) in 2003, leading to the establishment of UN Water in September 2003 (Chief Executive Board 2003a).

\section{Mandate}

UN-Water aims to promote coherence and coordination of UN system-wide actions to implement the MDGs and the agenda of the WSSD; to facilitate synergies and joint efforts; to improve support to member states in achieving the MDGs and the JPOI; to enhance the credibility and visibility of the UN System; to coordinate programs, prioritize issues for systemwide action, and facilitate coordinated and effective responses by the UN System at the global, regional, and country level; to promote the elaboration and dissemination of UN systemwide positions, effective communication, and collaboration among the UN System, civil society, and private-sector partners; and to facilitate information exchange and policy dialogue at all levels (UN-Water 2003).

\section{Structure}

UN-Water has 30 members and 26 partners; 4 have a special status, as of September 2012. It has Senior Programme Managers (SPMs), programs, regional arrangements, task forces, and Thematic Priority Areas. The SPM guides highlight the scope for rationalization and improving accountability and delivery, and may establish time-bound task forces on specific areas (UN-Water 2008), but has no direct authority to remove gaps and overlaps between the member's mandates. The four programs working under UNWater's aegis are more independent than the task forces and recently have been coordinated by a Joint Steering Group (UNWater, unpublished report). The Thematic Priority Areas address issues that are likely to stay at the forefront of UNWater's concerns for a longer time period. Additionally, UNWater operates through regional arrangements.

The chair and cochair of UN-Water are elected by UN-Water members on a rotating basis. The chair, cochair, and secretary are supported through a Technical Secretariat with three staff members located at the United Nations Department for Economic and Social Affairs (UN DESA) in New York. Like UN-Energy, UN-Water reports to the Chief Executives Board through the High-Level Committee on Programs (UN-Water 2003).

A Multi-Donor Trust Fund (MDTF; budget, USD 2 million annually) was established to strengthen UN-Water's activities and programs and to support core functions and specific projects and task forces initiated through UN-Water but executed by its members (UN-Water 2008, Schubert 2010). The United Nations Office for Project Services (UNOPS) and the Joint Steering Group administer the MDTF. Additionally, some projects are able to raise their own financial support from donors as, for example, the UN-Water Task Force on Sanitation.

\section{Activities}

UN-Water has task forces that contribute to regional and global conferences such as the World Water Week, organize workshops and seminars, map activities of UN-Water members, and prepare policy briefs and other publications. The UN-Water Task Force on Sanitation aims to support global efforts to reach the sanitation targets of the MDGs through, inter alia, the organization of the International Year of Sanitation. The Task Force on Gender and Water aims to promote gender mainstreaming in the implementation of the MDGs and the JPOI at all levels. The Task Force on Transboundary Waters aims to act as a clearinghouse for good practices for transboundary water cooperation through policy briefs, the organization of World Water Day and high-level sessions at the World Water Forum 2009 (Schubert 2010). The Task Force on Country-Level Coordination assesses waterrelated national coordination mechanisms in eight pilot countries and reviews interactions of UN organizations with each other and with non-UN actors (UN-Water 2008). The former Task Force on Climate Change has been transformed into a thematic priority area and contributes to international conferences by pointing out water-related adaptation and mitigation issues and aims to support the climate negotiations (UN-Water 2010). Furthermore, UN-Water organized a Water Day at the Rio+20 2012 Summit, where a status report on integrated approaches to water resource management was released (UNEP 2012). UN-Water also prepared a key message for Rio+20, highlighting the crucial importance of sustainable water management for a green economy and reinforcing its activities in capacity building, knowledge generation, and the support of cooperation among national governments (UN-Water 2012a). It further aims to prepare decisions on post-2015 goals relating to drinking water, sanitation, and water management (Schubert 2010, UN-Water $2012 b)$.

Each of the four programs has its own mandate, work plans, budget, donors, and staff, and each is hosted by different agencies. Programs that predate UN-Water, i.e., the Joint Monitoring Programme and the World Water Assessment Programme and its World Water Development Report, work quite independently from UN-Water. However, there are efforts in aligning their activities with UN-Water's Task Forces and secretariat. A third key report of UN-Water is the Global Analysis and Assessment of Sanitation and DrinkingWater (GLAAS) Report of the WHO. The newer programs are called the UN-Water Decade Programme on Capacity Development (UNW-DPC) and the UN-Water Decade 
Fig. 2. Comparative mandates of UN-Water, UN-Energy, and UN Environment Management Group (UN EMG).

\section{UN Water}

\begin{abstract}
Promote coherence and coordination of UN System actions (MDG, WSSD)
\end{abstract}

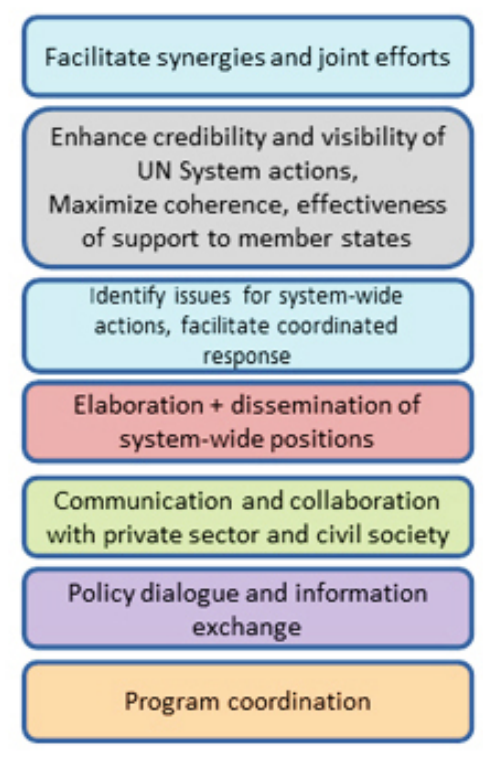

\section{UN Energy}

Help ensure coherence in the UN System and with non-UN stakeholders (WSSD)

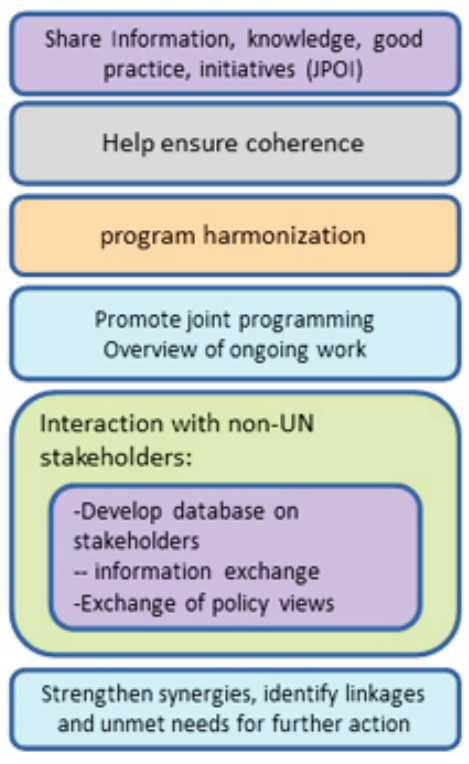

UN EMG

Coordinated response and action to newly emerging issues

Identify, address and resolve issues of inter-agency concern, promote interlinkages

Involvement of all important UN and non UN partners

Discussion and information/data sharing

Enhance the environment and human settlement perspective Assist UNEP and Habitat in the UN System interagency mechanism, especially the CSD

(add value to UN system interagency cooperation)

Compatibility of different approaches

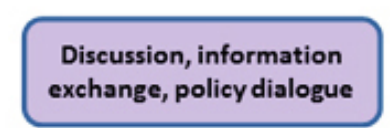

\section{Agreement on and dissemination of System- wide positions}

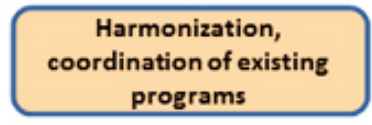

programs
Involvement of non-UN stakeholders
Identification of synergies, joint efforts
Coherence, Credibility and visibility of UN System actions
Programme on Advocacy and Communication and Support (UNW-DPAC), which support UN-Water and its Task Forces in knowledge building and capacity building and in developing communication and advocacy strategies (Schubert 2010).

\section{COMPARATIVE ASSESSMENT}

On the issue of mandate, the coordination bodies have similar overreaching goals: to ensure coherence and find a coordinated UN system-wide response to challenges in their work field. However, there are also differences: UN-Water's mandate focuses on activities to achieve the MDGs and has three goals at three governance levels. UN-Energy's mandate focuses on collaborating with private partners and aims to achieve, among other things, program harmonization and coherence. UN EMG's mandate highlights strengthening environmental and human settlement issues in the existing interagency mechanisms of the UN System. The elaboration and dissemination of a system-wide position is explicit in UN-
Water's mandate, partially so in UN EMG's mandate, and is not mentioned in UN-Energy's mandate (see Fig. 2). Furthermore, UN EMG was established following a General Assembly Resolution (United Nations General Assembly 1999), whereas the mandates of UN-Water and UN-Energy do not emerge from a comparable high-level decision. Figure 2 presents an overview of the main tasks defined in the mandates. The colors reflect similarities in the mandates, explained beneath.

In terms of structure, the coordination bodies have some similarities: (a) they are nonhierarchical network mechanisms connecting others without affecting existing power structures; (b) they are lean bodies, their secretariats are provided by UNEP and DESA with few staff members; (c) they have limited independent financial resources, depending on the inkind contributions of the members; their publications are partly funded by contributions from members, partners, or 
Table 1. Assessing the three bodies.

\begin{tabular}{|c|c|c|c|c|c|c|}
\hline & \multicolumn{2}{|c|}{ UN EMG } & \multicolumn{2}{|c|}{ UN-Energy } & \multicolumn{2}{|c|}{ UN-Water } \\
\hline & Comment & & Comment & & Comment & \\
\hline \multicolumn{7}{|l|}{ Substantive } \\
\hline Overview existing work & Explicit & + & Explicit & + & Implicit & + \\
\hline Promote coherence & Explicit & + & Explicit & $+/-$ & Explicit & $+/-$ \\
\hline Promote joint programs/harmonization & Explicit & $+/-$ & Explicit & $+/-$ & Explicit & $+/-$ \\
\hline Share knowledge & Explicit & + & Explicit & $+/-$ & Explicit & $+/-$ \\
\hline Elaborate system-wide position & Partial & $+/-$ & Implicit & - & Explicit & + \\
\hline Disseminate position & Implicit & - & Implicit & - & Explicit & $+/-$ \\
\hline Coherent support to states & Implicit & - & Explicit & + & Explicit & $+/-$ \\
\hline Enhance visibility of UN & Implicit & - & Implicit & - & Explicit & + \\
\hline \multicolumn{7}{|l|}{ Financial and organizational } \\
\hline Institutional inbedding & Higher & $+/-$ & Low & - & Low & - \\
\hline Interaction with NGOs & Implicit & - & Explicit & - & $\begin{array}{l}\text { Explicit; } \\
\text { permanent }\end{array}$ & + \\
\hline Manpower & Low & - & Low & - & Low & - \\
\hline Core funding & Low & - & Low & - & Low & - \\
\hline \multicolumn{7}{|l|}{ Steering capacity } \\
\hline Mandate & Implicit & - & Implicit & - & Higher & $+/-$ \\
\hline Hierarchy/ authority & Low & - & Low & - & Low & - \\
\hline Institutional links to processes & High & $+/-$ & Low & - & Low & - \\
\hline Institutional links to actors & Low & - & Low & - & Higher & $+/-$ \\
\hline Resources & Low & - & Low & - & Low & - \\
\hline
\end{tabular}

other donors; (d) their members are autonomous organizations and represent a heterogeneous context; and (e) they have limited authority to direct and execute projects or implement decisions (Wilson-Grau and Nunez 2006).

Interviews reveal that the advantages of a coordinating network body compared to other organizational forms are that they are usually organizationally nimble with limited bureaucracy and are better at adapting to change. A disadvantage is determining accountability: UN-Water and UN-Energy have rotating chairmanships and diverse leaders of the task forces. Authority and responsibility are flowing from and around members, and the way the organization is presently structured leads to unclear accountability. This is partly because water and energy do not fall under the remit of any existing organization. UN-Water and UN-Energy are linked to the HLCP and the Chief Executives Board, which are mandated to ensure coordination but are not the natural focal points for global water or global energy governance. However, this problem is less present in UN EMG because of its organizational proximity to UNEP. Because the international community has decided to considerably strengthen the coordination role of UNEP (United Nations 2012), it is likely that UN EMG will also become stronger in the future.

On the issue of activities, the coordination bodies (a) identify and address issues of system-wide concern in their work field; (b) provide an overview of ongoing work and their members' activities on different issue-areas; and (c) provide a forum for discussion and information sharing. However, their ability to strengthen coherence is limited: UN-Water and UN-Energy have outputs (coordinated responses or common positions published in policy briefs, in information material, or presented at conferences) that are not institutionally linked to policy processes. They are not responses to formal demands, and do not feed into existing processes, but are like freefloating advice; for more details on UN-Water see Baumgartner (2010). UN-Energy's coordination efforts in the clusters further reflect missing linkages inside its work field and between the clusters and missing support from team members who are not cluster leaders (UN-Energy 2009). This makes it difficult to overcome existing coordination deficits between the different angles in its work field. However, UN EMG's work is better institutionalized because of its close link to UNEP, and its work responds to evolving policy decisions of UNEP, such as in relation to biodiversity targets.

The ability to link with non-UN activities depends on the membership. UN-Water offers permanent membership to nonUN stakeholders and actively involves its partners in activities like the task forces. The other two bodies do not have such permanent cooperation. In UN-Energy, the cooperation with the private sector is limited, and UN EMG cooperates merely on an ad hoc basis. Table 1 summarizes the findings and 
provides an overview on the mandates, their fulfillment, the organizational setting, and the capacity of the three bodies.

\section{CONCLUSION: MANDATE IS CONTRADICTORY}

Of the many potential organizational design options for earth system governance, coordination bodies and high-level expert groups appear most feasible because they (a) are substantively attractive in that they aim at generating efficiencies in the system by enhancing synergies and reducing duplications (cf. United Nations 2012); (b) are politically attractive because they do not cause turf battles, long drawn-out legal and procedural conflicts, or call for an overhaul of existing organizations and their mandates; (c) are economically attractive because they are cheaper to organize in practical terms, having limited mandates, costs of office space, manpower, and running expenses, and have fewer field projects; and (d) are small so they are more nimble and able to manoeuver. This is confirmed by the interviews and by the global consensus on the need for coordination and coherence (United Nations 2012).

The questions are: (1) are coordination mechanisms actually able to coordinate?, and (2) which features enhance their ability to coordinate? Taking the second question first, we identify three design features that perhaps improve the ability of coordination mechanisms to enhance synergies. First, an institutional link to a body that has a clear mandate on the issue enhances the coordinating ability of a body. For example, EMG's institutional link to UNEP, the center of environmental work in the UN, makes it relatively more effective. There is no body comparable to UNEP on water or on energy, and this may limit the effectiveness of other coordination mechanisms. A structure comparable to those of UN EMG could also have disadvantages for a coordination body in the water or energy field, because it is more "exclusive" and is adapted to the interests and needs of a few organizations, mainly influencing the work program. In complex work fields like those of UNWater and UN-Energy, such a structure could be, perhaps, less applicable.

Second, when a coordination body's outputs are linked to institutional processes, there is a greater likelihood of enhancing synergies. The advantages of UN EMG, especially its closer linkages to global decision-making processes because of its organizational proximity to UNEP, may suggest the conclusion that UN-Water and UN-Energy should have a similar structure. Third, when a coordination body allows formal relationships with non-UN agencies, this may enhance its outreach. UN-Water has such partners. However, all these three conclusions should be seen more as hypotheses that need further testing.

Clearly, coordination would not be needed if there were no diverging and competing mandates, visions, policies, programs, and activities in specific issue areas. Coordination is relatively easy when the mandates, visions, policies, and programs are synergetic and only call for links to improve efficiencies in the system. However, when there are differences, coordination also implies some degree of steering to prevent overlaps, to fill gaps, and to minimize divergence of opinions. This can be done through diplomatic argumentation, but may often require some kind of hierarchical or substantive authority and resources. The organizations studied aim to be network bodies, moderating and coordinating existing $\mathrm{UN}$ agencies without adding to the bureaucracy. On the other hand, their mandate wants them to strengthen coherence and to coordinate programs and activities of their members, which are challenging tasks whose success mainly depends on the willingness of the members to cooperate. This is difficult, and so sometimes the coordination bodies undertake independent projects, which further confuses their coordination mandates. The irony is that the very feasibility of such bodies, their low financial and political cost in terms of upsetting the existing power structures, may also imply a low ability to rapidly steer the international community toward sustainable governance in all fields, but particularly also in the water field. This is especially the case when sustainable development actually calls for restructuring the way we produce, distribute, trade, and consume, rather than for incremental change.

Responses to this article can be read online at: http://www.ecologyandsociety.org/issues/responses. $\mathrm{php} / 5440$

\section{Acknowledgments:}

Susanne Schubert is a researcher at the Chair for Spatial and Infrastructure Planning at the Technical University of Darmstadt. She would like to thank her interview partners, as well as her MSc supervisors, Joyeeta Gupta, Martin Wickel, and Cathrin Zengerling. Joyeeta Gupta is Professor of Climate Change Policy and Law at the Institute for Environmental Studies, VU University Amsterdam, and Professor of Water and Environmental Policy and Law at UNESCO-IHE Institute for Water Education in Delft. She would like to thank the Global Water System Project for financing the workshop that enabled discussion of this paper. Both authors would like to thank Josefina Maestu, Kilaparti Rama-krishna, and William Cosgrove for their support in the writing process of this paper.

\section{LITERATURE CITED}

Agarwal, A., S. Narain, and A. Sharma. 1999. Green politics: global environmental negotiations. Centre for Science and Environment, New Delhi, India.

Bauer, S., S. Andresen, and F. Biermann. 2012. International bureaucracies. Pages 27-44 in F. Biermann and P. Pattberg, 
editors. Global environmental governance revisited. MIT Press, Cambridge, Massachusetts, USA.

Baumgartner, T. 2010. UN Water and its role in global water governance. Thesis. Albert-Ludwigs-University, Freiburg, Germany.

Biermann, F. 2002. Strengthening green global governance in a disparate world society: would a world environment organisation benefit the South? International Environmental Agreements: Politics, Law and Economics 2(4):297-315.

Biermann, F., K. Abbott, S. Andresen, K. Bäckstrand, S. Bernstein, M. M. Betsill, H. Bulkeley, B. Cashore, J. Clapp, C. Folke, A. Gupta, J. Gupta, P. M. Haas, A. Jordan, N. Kanie, T. Kluvánková-Oravská, L. Lebel, D. Liverman, J. Meadowcroft, R. B. Mitchell, P. Newell, S. Oberthür, L. Olsson, P. Pattberg, R. Sánchez-Rodríguez, H. Schroeder, A. Underdal, S. C. Vieira, C. Vogel, O. R. Young, A. Brock, and R. Zondervan. 2012a. Transforming governance and institutions for global sustainability: key insights from the Earth System Governance Project. Current Opinion in Environmental Sustainability 4(1):51-60. http://dx.doi. org/10.1016/j.cosust.2012.01.014

Biermann, F., K. Abbott, S. Andresen, K. Bäckstrand, S. Bernstein, M. M. Betsill, H. Bulkeley, B. Cashore, J. Clapp, C. Folke, A. Gupta, J. Gupta, P. M. Haas, A. Jordan, N. Kanie, T. Kluvánková-Oravská, L. Lebel, D. Liverman, J. Meadowcroft, R. B. Mitchell, P. Newell, S. Oberthür, L. Olsson, P. Pattberg, R. Sánchez-Rodríguez, H. Schroeder, A. Underdal, S. C. Vieira, C. Vogel, O. R. Young, A. Brock, and R. Zondervan. 2012b. Navigating the anthropocene: improving earth system governance. Science 335:1306-1307. http://dx.doi.org/10.1126/science.1217255

Chief Executives Board. 2002. CEB/2002/4, Report of the High-level Committee on Programmes on its third regular session, Appendix I: HLCP terms of references. UN, New York, New York, USA.

Chief Executives Board. 2003a. CEB/2003/2, Summary of conclusions of the United Nations System Chief Executives Board for Coordination at its second regular session of 2003. UN, New York, New York, USA.

Chief Executives Board. 2003b. CEB/2003/7, Report of the High-Level Committee on Programs at its sixth session. Rome, 18-19 September 2003. UN, New York, New York, USA.

Dellapenna, J., and J. Gupta. 2008. Toward global law on water. Global Governance: a Review of Multilateralism and International Organizations 14(4):437-453.

Dellapenna, J., and J. Gupta, editors. 2009. The evolution of the law and politics of water. Springer Verlag, Dordrecht, The Netherlands.
Environment Management Group. 2011. Working towards a balanced and inclusive green economy. Secretariat of the Environment Management Group, Geneva, Switzerland.

Environment Management Group, Issue Management Group on the 2010 Biodiversity Targets. 2009. Report of the first meeting, Paris, France. Secretariat of the Environment Management Group, Geneva, Switzerland.

Environment Management Group Secretariat. 2010. Terms of reference for the issue management group on a "green economy." Secretariat of the Environment Management Group, Geneva, Switzerland.

Environment Management Group of the United Nations Environment Programme. 2001. Harmonization of information management and reporting for biodiversity related treaties. Secretariat of the Environment Management Group, Geneva, Switzerland.

Esty, D. C. 1994. The case for a global environmental organisation. Pages 287-309 in P. B. Kenen, editor. Managing the world economy, fifty years after Bretton Woods. Institute for International Economics, Washington, D.C., USA.

Florini, A., and B. K. Sovacool. 2009. Who governs energy? The challenges facing global energy governance. Energy Policy 37:5239-5248. http://dx.doi.org/10.1016/j.enpol.2009.07.039

Gibson, R., editor. 1999. Voluntary initiatives: the new politics of corporate greening. Broadview Press, Peterborough. New Hampshire, USA.

Goldthau, A., and J. M. Witte. 2009. Back to the future or forward to the past? Strengthening markets and rules of effective global energy governance. International Affairs 85 (2):373-390. http://dx.doi.org/10.1111/j.1468-2346.2009.00798. $\underline{\mathrm{X}}$

Gosovic, B. 1992. The quest for world environmental cooperation: the case of the UN Global Environment Monitoring System. Routledge, London, UK.

Governing Council of the United Nations Environment Program / Global Ministerial Environment Forum. 2004. Eighth special session, UNEP/GCSS.VIII/8, 29-31 March, 2004, Jeju, Korea. UNEP, Nairobi, Kenya.

Gupta, J. 2002. Global sustainable development governance: institutional challenges from a theoretical perspective. International Environmental Agreements: Politics, Law and Economics 2(4):361-388.

Gupta, J. 2005. Global environmental governance: challenges for the south from a theoretical perspective. Pages 57-83 in $\mathrm{F}$. Biermann and S. Bauer, editors. A world environment organization: solution or threat for effective international environmental governance. Global Environmental Governance Series, Ashgate, Surrey, UK. 
Gupta, J. 2012. Global energy governance in the twenty-first century: challenges and opportunities. Pages 427-448 in M. P. Amineh and Y. Guang, editors. Secure oil and alternative energy: the geopolitics of energy paths of China and the European Union. Brill, Leiden, The Netherlands. http://dx. doi.org/10.1163/9789004233324015

Gupta, J., and A. Ivanova. 2009. Global energy efficiency governance in the context of climate politics. Energy Efficiency 2(4):339-352. http://dx.doi.org/10.1007/s12053-008-9036-4

Karlsson-Vinkhuyzen, S. I. 2010. The United Nations and global energy governance: past challenges, future choices. Global Change, Peace \& Security 22(2):175-195. http://dx. doi.org/10.1080/14781151003770820

Keohane, R. O. 1993. The effectiveness of international environmental institutions. Pages 3-24 in P. M. Haas, R. O. Keohane, and M. A. Levy, editors. Institutions for the earth. MIT Press, Cambridge, Massachusetts, USA.

Oberthür, S. 2002. Clustering of multilateral environmental agreements: potentials and limitations. International Environmental Agreements: Politics, Law and Economics 2 (4):317-340. http://dx.doi.org/10.1023/A:1021364902607

Pahl-Wostl, C., J. Gupta, and D. Petry. 2008. Governance and the global water system: a theoretical exploration. Global Governance: A Review of Multilateralism and International Organizations 14(4):419-435.

Pattberg, P. 2012. Transnational environmental regimes. Pages 97-122 in F. Biermann and P. Pattberg, editors. Global environmental governance revisited. MIT Press, Cambridge, Massachusetts, USA.

Schubert, S. 2010. Do the UN coordination bodies fulfill their coordination function? A case study of UN-Water, UN-Energy and UN EMG. Thesis. HafenCity University, Hamburg, Germany.

Tienhaara, K., A. Orsini, and R. Falkner. 2012. Global corporations. Pages 45-68 in F. Biermann and P. Pattberg, editors. Global environmental governance revisited. MIT Press, Cambridge, Massachusetts, USA.

UN-Energy. 2004. Report of the first session of UN-Energy, Paris, France. UN, New York, New York, USA.

UN-Energy. 2005a. Report of the third session of UN-Energy, Washington, D.C., USA. UN, New York, New York, USA.

UN-Energy. 2005b. Report of the sixth session of UN-Energy, Addis Ababa, Ethiopia. UN, New York, New York, USA.

UN-Energy. 2007. Report on UN-Energy video conference, 12 January. UN, New York, New York, USA.

UN-Energy. 2008a. Minutes of UN-Energy video-conference, 21 October. UN, New York, New York, USA.
UN-Energy. 2008b. Minutes of UN-Energy seminar and general meeting, 25-26 February, Vienna International Centre, Vienna, Austria. UN, New York, New York, USA.

UN-Energy. 2008c. Minutes of UN-Energy video-conference, 30 April. UN, New York, New York, USA.

UN-Energy. 2009. Minutes of UN-Energy, 30 March, Washington D.C., USA. UN, New York, New York, USA.

United Nations. 1945. Charter of the United Nations and Statute of the International Court of Justice. UN, San Francisco, California, USA.

United Nations. 2012. Report of the United Nations conference on sustainable development, A/CONF.216/16, Rio de Janeiro. UN, New York, New York, USA. [online] URL: http://www. uncsd2012.org/content/documents/814UNCSD\%20REPORT\% 20final\%20revs.pdf

United Nations Environment Programme (UNEP). 2005. Organization profile. UNEP, Nairobi, Kenya. [online] URL: http://www.unep.org/PDF/UNEPOrganizationProfile.pdf

United Nations Environment Programme (UNEP). 2007. Global environment outlook (GEO) 4. UNEP, Nairobi, Kenya.

United Nations Environment Programme (UNEP). 2012. The $U N$-Water status report on the application of integrated approaches to water resources management. UNEP, Nairobi, Kenya.

United Nations General Assembly. 1999. Fifty-third session: report of the Secretary-General on environment and human settlements, A/RES/53/242. UN, New York, New York, USA.

United Nations Secretary-General's High-Level Panel. 2006. Delivering as one. UN, New York, New York, USA.

United Nations Secretary-General's High-Level Panel on Global Sustainability. 2012. Resilient people, resilient planet: a future worth choosing. UN, New York, New York, USA.

United Nations Sustainable Development. 1992. United Nations Conference on Environment \& Development Rio de Janeiro, Brazil, 3 to 14 June 1992: Agenda 21. UN, New York, New York, USA.

UN-Water. 2003. Terms of references. UN, New York, New York, USA. [online] URL: http://www.unwater.org/ downloads/UNW-terms-of-reference.PDF

UN-Water. 2008. UN-Water operational guidelines. UN, New York, New York, USA. [online] URL: http://www.unwater. org/downloads/UN-Water_Operational_Guidelines.pdf

UN-Water. 2010. Water country briefs. UN, New York, New York, USA. [online] URL: http://www.unwater.org/ WaterCountryBriefs.html 
UN-Water 2012a. Water in a green economy: a statement by $U N$-Water for the UN Conference on Sustainable Development 2012 (Rio+20 Summit). UN, New York, New York, USA. [online] URL: http://www.unwater.org/downloads/

UNW RIOSTATEMENT.pdf

UN-Water 2012b. Deliverables by UN-Water for the Rio+20 United Nations Conference on Sustainable Development. UN, New York, New York, USA. [online] URL: http://www. unwater.org/downloads/UNWater_Deliverables_Rio20_vs30Mar. pdf

von Moltke, K. 2002. Governments and international civil society in sustainable development: a framework. International Environmental Agreements 2(4):341-359.

Wilson-Grau, R., and M. Nunez. 2006. Evaluating international social change networks: a conceptual framework for a participatory approach. Development in Practice 17(2): 258-271. http://dx.doi.org/10.1080/09614520701197226

World Summit on Sustainable Development (WSSD). 2002. Johannesburg Declaration on Sustainable Development. Report A/CONF./199/20, UN, New York, New York, USA.

Young, O. 2002. The institutional dimensions of environmental change. MIT Press, Cambridge, Massachusetts, USA. 